\title{
Pengembangan Modul Belajar Mandiri LaTeX Beamer Sebagai Alternatif Media Presentasi Mahasiswa Program Studi Pendidikan Matematika
}

\author{
Moh. Agung Arif ${ }^{1}$, Abdillah $^{2}$ \\ ${ }^{1,2}$ Pendidikan Matematika, Universitas Muhammadiyah Mataram, Indonesia \\ ${ }^{1}$ m.agungarif@gmail.com, ${ }^{2}$ ahmad fawwaz18@yahoo.co.id
}

\section{INFO ARTIKEL}

Riwayat Artikel:

Diterima: 30-08-2018

Disetujui: 22-10-2018

\section{Kata Kunci:}

Belajar Mandiri, LaTeX Beamer, Presentasi

\section{A. LATAR BELAKANG}

Pendidikan di Indonesia pada khususnya sangat diperhatikan oleh pemerintah terbukti dengan besarnya biaya yang di anggarkan untuk meningkatkan kualitas dari pendidikan yang ada di Indonesia. Pemerintah mengerti dan memahami bahwa kualitas pendidikan di Indonesia menjadi prioritas utama dalam membangun bangsa ini.

\begin{abstract}
Abstrak: Seorang mahasiswa dalam perkuliahan diwajibkan untuk mampu mempresentasikan apa yang telah didapat, dalam hal tugas perkuliahan secara umum sangat diperlukan media presentasi yang layak. Mahasiswa matematika tidak menutup kemungkinan untuk melakukan presentasi terutama ketika menempuh mata kuliah micro-teaching. Media presentasi sangat beragam mulai dari microsoft power point, google presentation, dan open office. Namun pada kenyataannya dalam hal penulisan matematika, media - media tersebut sangat sulit untuk mempresentasikan apa yang menjadi tujuan kita, terutama ketika sampai kepada sintaks- sintaks dan simbol simbol matematika. Beamer salah satu document class dari LaTeX menjadi harapan mahasiswa matematika yang ingin mudah untuk presentasi, namun kurangnya bahan ajar menjadikannya lebih sulit, oleh karena itu muncul gagasan untuk membuat bahan ajar berbentuk modul LaTeX Beamer ini untuk mempermudah mahasiswa yang ingin belajar. Model pengembangan yang digunakan adalah PPE (Planning Production Evaluation). Sampel penelitian adalah seluruh mahasiswa semester V, instrumen yang dipakai hanya angket penilaian terhadap modul. Berdasarkan analisis data, disimpulkan bahwa penelitian yang dilakukan menggunakan PPE mendapatkan ratarata penilaian dengan 20 butir soal penilaian dengan nilai rata - rata sebesar 4,4 yang berarti "sangat valid" untuk digunakan mahasiswa sebagai bahan ajar mandiri.
\end{abstract}

\begin{abstract}
A student in the lecture is required to be able to present what has been obtained, in terms of lecture assignments in general it is necessary to have a decent presentation media. Mathematics students do not rule out the possibility to make presentations especially when taking micro-teaching courses. Media presentations are very diverse starting from Microsoft Power Point, Google Presentation, Open Office. But in reality in terms of mathematical writing, these media are very difficult to present what is our goal, especially when it comes to syntaxes and mathematical symbols. Beamer, one of the document classes from LaTeX, is the hope of mathematical students who want to be easy for presentations, but the lack of teaching materials makes it more difficult, therefore the idea to create teaching materials in the form of LaTeX Beamer modules is made easier for students who want to learn. The development model used is PPE (Planning Production Evaluation). The research sample was all $V$ semester students, the instrument used was only a questionnaire assessment of the module. Based on data analysis, it was concluded that research carried out using PPE obtained an average rating with 20 items of assessment with an average value of 4.4 which means "very valid" for students to use as independent teaching materials.
\end{abstract}

Guru menjadi pemegang kendali dalam menentukan arah sebuah pendidikan berjalan dengan baik dan menghasilkan mutu yang berkualitas, menjadi seorang guru tentulah tidak gampang harus di raih dengan susah payah. Menjadi seorang mahasiswa di Fakultas Ilmu Pendidikan dan Keguruan (FKIP) merupakan sebuah perjalanan menjadi seorang guru yang profesional, karena di tunjang dari berbagai aspek unggul untuk memenuhi 
kebutuhan menjadi seorang guru mulai dari kurikulum, bahan ajar, sikap, sopan santun dan lain lain. Ditempat secara khsusus untuk menjadikan seorang mahasiswa keguruan menjadi calon guru yang unggul dan profesional. Perjalanan menjadi seorang mahasiswa sampai pada menjadi sarjana keguruan tidaklah mudah, banyak menemui hambatan mulai dari kemampuan kognitif mahasiswa itu sendiri sampai dengan kemampuan mahasiswa untuk beradaptasi dengan kemajuan dari teknologi yang sudah ada.

Kuliah sekarang ini sangat dimudahkan dengan adanya teknologi yang canggih, namun terkadang tidak semua orang berakselerasi sejalan dengan meningkatnya kemampuan teknologi, ini menyebabkan perlambatan di bidang teknolgi untuk sekelas seorang mahasiswa.

Presentasi menjadi salah satu hal yang sangat lumrah dalam dunia perkuliahan, presentasi merupakan cara seorang pengajar unuk melihat kemampuan dari mahasiswa apakah telah mampu menguasai materi yang diberikan atau tidak. Dalam hal presentasi mahasiswa sudah sangat dimudahkan dengan adanya media presentasi yang banyak sekarang ini mulai dari Microsoft Office Power Point, Open Office Presentation dan banyak lagi yang lainnya.

Matematika di zaman sekarang ini telah banyak mengalami perubahan yang signifikan, mulai dari hal - hal yang mudah untuk dimengerti dan sulit untuk dipahami, dalam hal teknologi matematika sudah dimudahkan seperti kehadiran alat hitung, kamus online matematika, namun masih banyak mahasiswa program studi matematika yang belum mampu untuk berjalan dengan perkembangan teknologi sekarang ini, terbukti dengan banyak mahasiswa matematika yang masih menggunakan media presentasi yang sebenarnya masih kurang tepat untuk seorang mahasiswa matematika yang sangat carry on dengan hal hal seperti simbol dan lambang yang tidak ada pada media presentasi yang biasa digunakan.

Media penulisan untuk seorang mahasiswa Jurusan MIPA terutama matematika sudah ada sejak lama, adalah $L a T e X$ menjadi media penulisan yang lebih mumpuni untuk seorang mahasiswa prodi matematika, namun pada kenyataan yang ditemukan masih banyak mahasiswa matematika yang tidak dapat mengoperasikan dan bahkan tidak tahu apa itu LaTeX. Bemamer menjadi salah satu class yang cukkup penting dalam LaTeX, karena Bemaer merupakan class media presentasi untuk seorang mahasiswa Jurusan MIPA pada umumnya dan Matematika pada khususnya. Untuk memudahkan presentasi dalam materi matematika dapat digunakan LaTeX Bemaer sebagai media presentasi,namun pda kenyataannya masih banyak masiswa yang belum tahu tentang hal ini. Berdasarkan hal tersebut peneliti ingin meneliti dan mengembangkan sebuah bahan ajar madiri tentang bagaimana membuat sebuah presentasi menggunakan LaTeX Bemaer untuk dipergunakan mahasiswa prodi matematika pada khususnya.

\section{B. METODE PENELITIAN}

\section{Model Pengembangan}

Seperti yang dipaparkan Richey and Klein dalam Sugiyono (2015: 39) model pengembangan yang digunakan dalam penelitian ini adalah model Planning Production Evaluation (PPE), fokus dari penelitian pengembangan ini bersifat analisis dari awal hingga akhir, yang meliputi perancangan, produksi, dan evaluasi.

\section{Prosedur Pengembangan}

Dari masalah kurangnya bahan ajar untuk LaTeX Beamer, penelitian ini diharapkan dapat menghasilkan sebuah produk berbentuk bahan ajar LaTeX Beamer, maka masuklah ke tahap merancang produk sebagaimana disesuaikan dengan kevalidan, keefesienan dan kepraktisan modul. Setelah modul di rancang maka desain modul tersebut divalidasi (diuji secara internal) oleh ahli dan praktisi. Berdasarkan saran dari ahli dan praktisi desain modul tersebut diperbaiki (revisi) secara internal.

Berdasarkan hasil revisi, selanjutnya desain dari modul tersebut mulai diproduksi aawal. Setelah produk awal jadi, maka produk tersebut diuji lapangan secara terbatas. Menurut Borg dan Gall dalam Sugiyono (2015: 49) apabila produk tersebut merupakan produk pendidikan, maka produk tersebut harus diuji terbatas pada tiga sekolah dengan menggunakan $6-12$ subjek, hasil dari uji terbatas lalu dijadikan acuan revisi produk selanjutnya.

Berdasarkan hasil revisi dari uji terbatas, maka dapat dilakuan uji lapangan. Menurut Borg dan Gall dalam Sugiyono (2015 : 49) uji lapangan utama dapat dilakukan 5 sampai dengan 15 sekolah dengan menggunakan 30 sampai dengan 100 subyek (anggota sampel), setelah uji lapangan maka akan didapat apakah produk tersebut dapat dikatakan valid atau tidak untuk digunakan selamjutnya.

\section{Uji Coba Produk}

Uji coba produk akan dilaksanakan dalam tiga tahap yaitu: (1) Planning. Dalam tahap pertama ini akan dilaksaanakan beberapa hal diantaranya: (a) Merancang Produk,

a. Validasi Design. Rancangan yang telah ada lalu di validasi oleh ahli, yaitu: (1) Ahli Bahasa. Ahli bahasa yang dimaksudkan adalah minimal seorang dosen S2 Pendidikan Program Studi Bahasa dan Sastra Indonesia yang ada di Univeersitas Muhammadiyah mataram, dimana nanti ahli bahasa yang memiliki peranan dalam mengoeksi serta memvalidasi desain modul yang telah dibuat; (2) Ahli Design Grafis. Ahli desain grafis yang dimaksudkan adalah minimal dosen S2 dalam 
bidang komputer, atau dosen prodi matematika yang berkompeten dalam bidang ini; (3) Ahli Materi. Ahli materi dalam hal ini adalah minimal dosen S2 yang mengerti tentang LaTeX dan class Beamer.

b. Revisi Desain. Hasil masukan dari para ahli kemudian menjadi acuan untuk merivisi produk sebelum produk siap untuk diuji coba dalam skla kecil.

c. Pembuatan produk. Setelah direvisi, maka produk siap dibuat dan diujicobakan.

d. Uji coba Terbatas. Uji coba terbatass dilaksanakan terhadap 5 orang dari seluruh jumlah mahasiswa yang ada sekitar 25 orang dengan cara pourpouse random sampling dengan kebutuhan mahasiswa yang berkemampuan lebih secara akademis.

e. Revisi. Revisi bisa dilakukan atau tidak dilakuan mengacu kepada hasil analisis, jika tidak memenuhi kategori kevalidan maka akan dilakukan revisi sesuai dengan kebutuhan dan selanjutnya melaksanakan uji coba utama dilapangan (akhir).

\section{Subjek Uji Coba}

Subjek uji coba dalam penilitian ini adalah:

a. Mahasiswa semester V Program Studi Pendidikan Matematika, Fakultas Keguruan dan Ilmu Pendidikan, Universitas Muhammadiyah Mataram yang berjumlah 25 orang sebagai subjek penelitian dalam uji coba terbatas dan uji coba utama. Penggunaan mahasiswa semester $\mathrm{V}$ mengacu kepada urgensi dari peneliti dan manfaat yang terimplikasi secara langsung kepada subjek, karena subjek akan menempuh mata kuliah microteaching dan segera terjun ke lapangan sebagai guru dalam program PPL.

b. Dosen Program studi matematika di Universitas Muhammadiyah Mataram atau dosen lain yang berkredibilatas dan memilih abilitas yang mumpuni dalam bidang LaTeX Beamer sebagai ahli materi, mengingat materi LaTeX Bemaer masih cukup Strange dikalangan mahasisawa matematika di Universitas Muhammadiyah Mataram.

c. Dosen Program Studi Bahasa Indonesia dan Daerah yang ada di Universitas Muhammadiyah Mataram yang berkompeten di bidangnya sebagai penguji (ahli) bahasa dalam modul yang akan dikembangkan nantinya.

d. Dosen Program Studi Matematika atau dosen yang berkompeten dalam bidang design grafis sebagai penguji (ahli) bentuk grafis dari modul yang akan dikembangkan.
Dalam penelitian ini ada beberapa jenis data yang diperlukan secara umum berupa data deskriptif dan kuantitatif dapat dijabarkan seperti berikut :

a. Data kuantitatif dari angket respon terhadap modul yang diisi oleh mahasiswa dalam skala kecil.

b. Data kuantitatif yang diperoleh dari hasil pengisian angket kesuaian materi oleh ahli mater.

c. Data deskriptif dari hasil pengisian angket kesesuaian materi oleh ahli materi.

d. Data kuantitatif yang diperoleh dari hasil pengisian angket kesesuaian grafis oleh ahli design grafis.

e. Data deskriptif yang diperoleh dari hasil pengisian angket kesesuaian grafis oleh ahli design grafis.

f. Data kuantitatif yang diperoleh dari hasil pengisian angket kesesuaian bahasa oleh ahli bahasa.

g. Data deskriptif yang diperoleh dari hasil pengisian angket kesesuaian bahasa oleh ahli bahasa.

h. Data kuantitatif yang diperoleh dari hasil pengisian angket respon terhadap modul yang diisi oleh mahaasswa dalam uji coba utama.

i. Data berupa gambar saat penelitian berlangsung baik pada uji coba skala kecil maupun uji coba utama.

Data yang tidak dicantumkan menyesuaikan dengan kebutuhan praktik dilapangan, akan di paparkan pada bab selanjutnya jika ada.

\section{Instrumen Pengumpulan Data}

a. Angket Respon Terhadap Modul. Angket respon terhadap modul digunakan untuk mengetahui seberapa respon objek penelitian terhadap modul untuk memenuhi kriteria kevalidan. Angket disusun berdasarkan skala Guttman sehingga data yang diperoleh berupa data interval atau rasio dikhotim (dua alternatif) yaitu "ya" atau "tidak".

b. Angket Penilaian Modul. Angket penilaian modul digunakan untuk memenuhi kriteria kevalidan pada tahap uji coba utama (akhir) dari penelitian ini, diisi oleh subjek penelitian. Angket ini disusun berdasarkan skala Likert, skala yang digunakan mulai dari "sangat setuju", "setuju", "ragu ragu" , "tidak setuju", dan "sangat tidak setuju". Skala ini memeliki skor dari satu sampai dengan lima.

c. Angket Kesesuaian Materi. Angket kesesuaian materi digunakan untuk mengetahui kesesuaian isi mater sudah layak digunakan atau tidak. Angket ini disusun dengan skala likert, skala yang digunakan mulai dari "sangat setuju", "setuju", "ragu ragu" , "tidak setuju", dan "sangat tidak setuju". Skala ini memeliki skor dari satu sampai dengan lima. 
d. Angket Kesesuaian Grafis. Angket kesesuaian grafis digunakan untuk mengetahui kesesuaiantata letak design dari modul ini sudah layak atau tidak. Angket ini disusun dengan skala likert, skala yang digunakan mulai dari "sangat setuju", "setuju", "ragu ragu", "tidak setuju", dan "sangat tidak setuju". Skala ini memeliki skor dari satu sampai dengan lima.

e. Angket Kesesuaian Bahasa. Angket kesesuaian bahasa digunakan untuk mengetahui kesesuaian bahasa apakah sudah layak digunakan atau tidak dalam modul. Angket ini disusun dengan skala likert, skala yang digunakan mulai dari "sangat setuju", "setuju", "ragu ragu" , "tidak setuju", dan "sangat tidak setuju". Skala ini memeliki skor dari satu sampai dengan lima.

f. Dokumentasi. Dokumentasi digunakan untuk mengabadikan proses penilaian terutama pada saat uji coba utama. Akan didapat beberapa gambar untuk mengabadikan momen - momen tersebut

\section{Teknik Analisis Data}

a. Analisis Angket Respon Terhadap Modul. Langkah - langkah dalam menganalisa data dari Lembar angket respon terhadap modul ini aadalah :

1) Mengubah skor dari skla Guttman menjadi angka jika "ya " maka akan bernilai 1 ,dan jika "tidak" akan bernilai 0 .

2) Menjumlahkan skor dari setiap butir pertanyaan.

3) Menghitung skor total rata - rata dari setiap komponen

4) Mengubah skor rata rata menjadi nilai dengan kategori.

b. Analisis Angket Kesesuaian Materi, design grafis, dan Bahasa

Adapun langkah langkah dalam menganalisis sebagai berikut :

1) Data yang masih berupa skala likert dikonversi menjadi data kuantitatif.

2) Tabulasi semua data yang diperoleh

3) Menghitung skor total rata - rata dari setiap komponen

4) Mengubah skor rata - rata menjadi nilai dalam kategori.

5) Konversi data kuantitatif menjadi data kualitatif menggunakan teori Sukardjo dalam (Yuliati, $2013: 45$ )

TABEL 1

KONVERSI DATA MENJADI KUALITATIF

\begin{tabular}{ccl}
\hline Rentang Skor & Persentase & Data Kualitatif \\
\hline $\bar{X}>4,2$ & $81 \%-100 \%$ & Sangat Baik \\
\hline $3,4<\bar{X} \leq 4,2$ & $61 \%-80 \%$ & Baik \\
\hline $2,6<\bar{X} \leq 3,4$ & $41 \%-60 \%$ & Cukup Baik \\
\hline
\end{tabular}

\begin{tabular}{ccl}
\hline $1,8<\bar{X} \leq 2,6$ & $21 \%-40 \%$ & Kurang baik \\
\hline$\leq \bar{X} 1,8$ & $0 \%-20 \%$ & $\begin{array}{l}\text { Sangat kurang } \\
\text { baik }\end{array}$ \\
\hline
\end{tabular}

Dalam penelitian ini nilai kelayakan secara kualitatif adalah minimal "cukup baik" atau mendapat nilai "C" . Jika nilai yang diperoleh minimal "C" maka modul ini dianggap layak untuk dipergunakan.

\section{HASIL DAN PEMBAHASAN}

\section{Hasil Ujicoba}

Hasil uji coba berdasarkan model pengembangan Planning Production Evaluation (PPE), diperoleh hasil dari analisis angket penilaian oleh ahli materi menunjukkan rata-rata sebesar 3,1 yang berarti angket "cukup valid" dan siap digunakan, hasil analisis penilaian modul oleh ahli bahasa menunjukkan bahwa modul siap digunakan dan termasuk dalam kategori valid (rata-rata sebesar 3,1), dan Hasil dari analisis penilaian modul oleh ahli desain menunjukkan bahwa modul termasuk dalam kategori valid dan siap digunakan dengan revisi.

Kemudian dari analisis penilaian modul secara terbatas menunjukkan bahwa modul termasuk kedalam kategori valid $(3,92)$ dan siap diujicoba lapangan. Kemudian berdasarkan hasil dari analisis penilaian modul pada 18 responden menunjukkan bahwa modul termasuk dalam kategori sangat valid dengan rata - rata 4,4 dan siap digunakan.

\section{Revisi Produk}

\section{a. Tahap Production (Produksi)}

Tahap Produksi dibagi menjadi dua bagian yaitu:

1) Tahap pembuatan produk

Produk yang telah valid dengan beberapa revisi yang telah dilakukan pada tahap sebelumnya ,selanjutkan di buat lagi dengan desain sebagai berikut.

a) Bagian pendahuluan

Sampul Depan

Peneliti mendesain sendiri sampul depan modul dengan menggunakan aplikasi Adobe Photoshop CC 2015.1 adapun bagian dari sampul depan meliputi.

(1) Judul Modul yaitu "Modul Mandiri LaTeX Beamer"

(2) Sasaran Modul yaitu "Mahasiswa Jurusan MIPA"

(3) Identitas Penulis Modul dari nama "Mohamad Agung Arif Z" , Prodi "Pendidikan Matematika"

(4) Gambar pendukung yaitu gambar yang berkaitan dengan LaTeX Beamer dan warna hijau ungu sebagai bentuk identitas kampus. 
Penampilan dari sampul depan modul seperti berikut

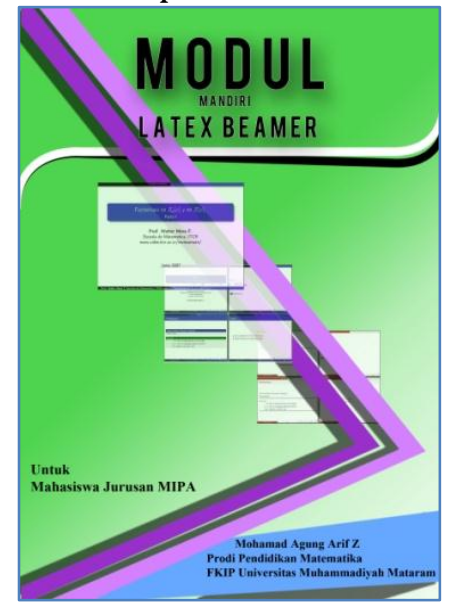

Gambar 2. Cover

Halaman Identitas

Halaman identitas berisi informasi tentang judul modul, sasaran modul, penulis pembimbing, penyunting, ukuran modul, dan aplikasi untuk pembuatan modul.

Halaman Kata Pengantar

Halaman kata pengantar berisi tentang pemaparan secara singkat perjalanan penulisan modul .

Bagian Isi

Bagian isi terbagi menjadi empat bagian yaitu.

(1) Bagian 1(Instalasi)

Bagian 1 berisikan tentang cara instalasi LaTeX Bemaer.

(2) Bagian 2(Mengenal TeXMaker) Bagian 2 berisikan tentang menubar, toolbar dan fungsi fungsinya pada TeXMaker.

(3) Bagian 3(Memulai Beamer) Bagian 3 berisi tentang memulai membuat presentasi menggunakan Beamer.

(4) Bagian 4(Beamer Tahap Lanjut)

Bagian 4 berisi tentang animasi, dekorasi dan pewarnaan pada presentasi menggunakan LaTeX Beamer.

Bagian Penutup

Bagian penutup berisikab beberapa bagian yaitu

(1) Daftar Tabel Tema Daftar tabel Tema berisikan tentang tema - tema standar yang dapat dipilih untuk digunakan pada presentasi.

(2) Daftar Tabel Lambang
Daftar tabel lambang merupakan tabel yang berisikan tentang lambang dan command yang digunakan pada LaTeX Beamer.

(3) Daftar Pustaka

Daftar pustaka berisikan tentang pudtaka yang digunakan selama pembuatan modul ini.

2) Ujicoba terbatas

Ujicoba terbatas dilakukan dengan memilih lima mahasiswa angkatan TA 2012/2013 yang dirasa cukup mengenal Beamer secara umum, lalu diberikan modul yang telah diproduksi (revisi), selanjutnya diberikan angket penilaian dan diisi secara rahasia independen tanpa campur tangan peneliti.

\section{b. Tahap Evaluation (Evaluasi).}

Tahap evaluasi hanya melakukan tes utama dengan sedikit revisi dari hasil uji coba produk secara terbatas

\section{SIMPULAN DAN SARAN}

Produk yang telah dilakukan revisi pada tahap akhir dapat dikaji secara mendalam dan memenuhi kesimpulan, yakni: (1) Modul LaTeX Beamer ini dihasilkan dengan tahapan pengembangan PPE (Planing, Produksi, Evaluasi); (2) Hasil dari modul ini termasuk kedalam kategori valid sesuai dengan penilaian pada angket yang diberikan kepada ahli materi dengan kategor "sangat valid" dengan skor 4,3; (3) Kualitas dari modul ini ditinjau dari sisi keefektifan dan keefisienan dirasa berkualitas dengan nilai kevalidan akhir 4,4 dan masuk kategori "Sangat Valid". Kemudian saran untuk pemanfaata dari modul ini yaitu: (1) Modul ini sesuai jika menggunakan editor TeXMaker 2.9; dan (2) Modul ini dibuat untuk dipergunakan secara mandiri, jadi cobalah untuk menggunakannya secara mandiri.

\section{REFERENSI}

[1] Astika Finka Fitri. (2014). Pengembangan Modul Matriks Dengan Pendekatan PMRI untuk siswa SMK kelas $X$.

[2] Khan Chandra. (2016). Introducing LaTeX(on playlist) [vicited 2016 Des. 19] From : URL: https://www.youtube.com/user/chandrahashbti.

[3] LaTeX/Advanced Mathematic. (2017), https://en.wikibooks.org/wiki/LaTeX/Advanced Mathematics.

[4] Sugiyono. (2015). Metode Penelitian \& Pengembangan Research and development. Bandung: CV. Alfabeta. 
[5] Hirwanto. (2014). Beamer Media Presentasi LaTeX Yogyakarta: LaTeX \& EPUB Publishing

[6] Hirwanto. (2015). Bemaer Media Presentasi LaTeX Yogyakarta: LaTeX \& EPUB Publishing.

[7] Winarno, Edy. (2011). Tools Presentasi terbaik. Jakarta: PT. Elex Media Komputindo.

[8] Widoyoko Eko Putro. (2009). Evaluasi Program Pembelajaran Yogyakarta: Pustaka Pelajar 